\title{
Institutionalizing corporate social responsibility: effects on corporate reputation, culture, and legitimacy in Malaysia
}

\begin{abstract}
Purpose: The purpose of this paper is to develop measures of Asian corporate social responsibility (CSR) based on David's dual process model for Malaysian government linked corporations (GLC) and publicly listed companies (PLC). Design/methodology/approach: A survey consisting was conducted and a structural equation model was used to test the relationships among constructs. An instrument to measure CSR practices focusing on CSR relational, CSR ethical/moral, and CSR discretionary is developed to evaluate impacts on corporate reputation, culture, and legitimacy. Findings: Findings suggest CSR antecedents emerge through formalization of corporate communication management in Malaysian organizations. The structural model provides evidence that CSR initiatives impact corporate reputation directly. The study acknowledges the increase in CSR initiatives in corporate communication practices in GLCs and PLCs in the quest to gain public legitimacy and corporate governance. Originality/value: The study contributes to the corporate communication literature by linking CSR to corporate reputation and culture, and developing a CSR model that explores a critical dimension in management of corporate identity in an Asian country.
\end{abstract}

Keyword: Corporate social responsibility; Corporate reputation; Institution; Malaysia; Social responsibility; Organizations 